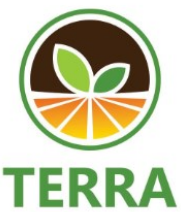

Journal of Land Restoration

\title{
Soil Properties Variability Under Various Agroecosystems In Ultisols Of Bengkulu
}

\author{
Priyono Prawito ${ }^{1 *}$, Impetus Hasada Windu Sitorus ${ }^{2}$, Zainal Muktamar ${ }^{1,}$ Bandi Hermawan ${ }^{1}$, \\ Welly Herman ${ }^{1}$ \\ ${ }^{1}$ Soil Science Department University of Bengkulu, Bengkulu, 38121, Indonesia \\ ${ }^{2}$ Agriculture Development Centre/Livestock Development Centre, ADC/LDC, Bengkulu, Indonesia \\ email :priyono@unib.ac.id
}

\begin{abstract}
Understanding the relation of agroecosystem types, ages, and soil properties are vital in maintaining good quality soil. This study aims to explore the variation of selected soil properties with agroecosystem types and ages. The research has been conducted in North Bengkulu, Indonesia. Soil properties on agroecosystems of 5-yr, 10-yr, 15-yr oil palm plantation, 5-yr, 10-yr, 15-yr rubber plantation, food cropland, and scrubland were evaluated. The study found that soil in oil palm and rubber plantations of any age have a similar texture, bulk density (BD), and actual soil moisture (ASM). All plantation agroecosystems and scrubland have higher clay and lower silt content than that in food cropland. In addition, the scrubland has the highest ASM content among the agroecosystems. On the other hand, both agroecosystems enhances soil chemical properties than food cropland and scrubland as indicated by the improvement of organic-C, total- $N$, available $P$, exchangeable $K$ and CEC of Ultisols. Older plantation also provides higher soil chemical improvement than younger one. This finding is significant for management of sub optimal soil mainly Ultisols for oil palm and rubber plantation.
\end{abstract}

Keywords : earthworm population, oil palm, rubber, Scrubland, understory vegetation

\section{INTRODUCTION}

Ultisols are the second more extensive area of soil order in Indonesia, covering more than 45 million hectares $(25 \%)$ and distributed in Kalimantan, Sumatera, Sulawesi, Papua, java and Nusa Tenggara. The largest Ultisols was located in Kalimantan (21.938.000 ha), followed by Sumatera (9.469.000 ha), Maluku and Papua (8.859.000 ha), Sulawesi (4.303.000 ha), Java (1.172.000 ha), and Nusa Tenggara (53.000 ha). Ultisols can be found in various relief from flat to hilly areas (GFW, 2018; Shofiyati et al. 2010; Prasetyo and Suriadikarta, 2006). In Bengkulu, Ultisols are also the second most extensive soil order covering more than $20 \%$ area of Bengkulu Province (Sukma WP., 1990). Because of their large covering areas, deep profile, and low to medium CEC, make Ultisols have an essential role in agriculture development in Indonesia. Ultisols in Indonesia are commonly used as oil palm and rubber estate and industrial forest on a large scale. Ultisols are well managed and offer a good revenue for the company. However, soils are not appropriately handled in small-scale farms due to limiting knowledge and resource, resulting in less profitable farms.

Ultisols are considered an advanced development of soil order, characterized by a deep soil profile due to intensive soil development processes promoted by high temperature and rainfall. Clay, as a result of mineral weathering, was transported and accumulated in the lower part of the soil profile to develop an argillic horizon. Because of its advanced leaching, most base cations such as $\mathrm{Ca}$, $\mathrm{Mg}, \mathrm{K}, \mathrm{Na}, \mathrm{Fe}$ are leached out from the soil profile resulting in low BS. Soil classified as a Ultisols has to meet the requirement of having an argillic horizon and low BS $(<35 \%)$ in the lower part of the argillic horizon (SSS, 2014). Ultisols are often associated with acid mineral soil, characterized by low $\mathrm{pH}, \mathrm{CEC}$, BS, Organic $\mathrm{C}$, and high saturated $\mathrm{Al}, \mathrm{P}$ fixation, and high $\mathrm{Fe}$ and $\mathrm{Mn}$ content, sometimes toxic. The presence of an argillic horizon decreases soil physical properties such as macro and 
micropores, which limit gravitational water movement and increase runoff. Ultisols also have low aggregate stability and are susceptible to soil erosion (Yulnafatmawita \& Adrinal, 2014). Naturally, Ultisols have low fertility because of their pedogenic processes.

Besides its pedogenic processes, land management, including the use of soil, affects the fertility of the soil. Previous studies reported that soil fertility decreased drastically after five years of forest and pasture land conversion to slash and burn agriculture. It is indicated by decreasing soil organic matter and nutrient content and deteriorating soil structure after the forest and pasture land conversion to agriculture (Emadi et al., 2009; Bahr et al., 2015; and Willy et al., 2019). Wu \& Tiessen (2002) reported that utilizing grassland for grazing in China decrease organic carbon (OC), total $\mathrm{N}$, and $\mathrm{CEC}$ by 33,28 , and $13 \%$ respectively, while for cultivation, decrease soil OC by 25,39 , and 55 $\%$ after 8-, 16-, and 41-yr of cultivation, respectively. Converting forest to cultivated land, in Ethiopia, CEC, clay, $\mathrm{Ca}^{2+}, \mathrm{Mg}^{2+}$, soil organic matter, and total $\mathrm{N}$ were decreased. In contrast, soil bulk density (BD) and sand content was an increase. This study also reported that the forest conversion did not affect silt, $\mathrm{Na}, \mathrm{K}$, and soil $\mathrm{pH}$ (Ebabu et al., 2003). The effects of forest conversion to different agroecosystems were responded differently (Samani et al., 2020). Generally, the more vegetation coverage of the land uses, the less distinct from the forest. After forest conversion, the texture was finer, N, P, $\mathrm{OC}$, and electric conductivity (EC) were lower than forest land. Samani et al. (2020) suggested that decreasing those soil properties was controlled by reducing organic matter content.

Jin et al. (2011) reported that good land management practices, such as organic manure application, straw returning to the land, could maintain soil fertility in good quality. The effect of multiple croppings such as rubber jungle and coffee plantation can also maintain soil fertility quality. Amoah et al. (2012) reported that adding cow dung manure can increase soil water-stable aggregate and water used efficiency. Samani et al. (2020) found that forest conversion to an orchard and various agroforestry types and ages can maintain soil $\mathrm{pH}$, silt, $\mathrm{Na}$, and $\mathrm{K}$ content, depending on the vegetation covering the land that controls soil organic matter.

Most Ultisols in Bengkulu are used as perennial or annual crops, such as oil palm, rubber and coffee plantations, or food crop, while some areas are letting as abandoned land covered with scrubs and grasses of various densities, indicating as a critical land. Naturally, land use controls the rate of soil-physical, -chemical, and -biological properties change, suggesting that soil properties are diverse according to the use of the soil. Besides the type of crops developed on the land, soil properties are also determined by the time or age of the agroecosystem (Bahr et al., 2015). There are not many studies on the effects of land-use type and age of agroecosystem in Ultisols Bengkulu. Understanding the relation of agroecosystem types, ages, and soil properties is vital in maintaining soil fertility of good quality. The purposes of this study are to explore the variation of selected soil properties with agroecosystem types and ages.

\section{MATERIALS AND METHODS}

The study has been conducted in the Agriculture Development Centre/Livestock Development Centre (ADC/LDC) Bengkulu, Indonesia. The site was located between $3^{\circ} 23^{\prime} 0^{\prime \prime}$ to $3^{\circ} 21^{\prime} 30^{\prime \prime}$ South and $102^{\circ} 8^{\prime} 0^{\prime \prime}$ to $102^{\circ} 9^{\prime} 0^{\prime \prime}$ East. The soil was described as Typic Hapludult, and located in undulating topography, ranging from 0 to $15 \%$ slope. It comprised various agroecosystems such as oil palm and rubber plantations of several ages, food crops, and scrubland abandoned for more than ten years. The research was arranged following RCBD involving a single factor treatment of agroecosystem, namely: 5-yr oil palm plantation (T1), 10-yr (T2), 15-yr (T3), 5-yr rubber plantation (T4), 10-yr (T5), 15-yr (T6), food crop (T7), and scrubland (T8). All treatments were repeated three times, where the repetition was nested in the agroecosystems. The tree plot size was $20 \mathrm{~m}$ wide by $20 \mathrm{~m}$ long. All plots were managed to place in a similar slope ranging from $5-10 \%$. Each field plot for oil palm plantation contains five stems and eight stems for the rubber plantation plot. The food crop and scrubland plots were $5 \mathrm{~m}$ wide by $10 \mathrm{~m}$ long. By the study, the food crop was a cornfield, and the corn had just been harvested.

Selected soil properties evaluated in this study were: soil texture that was determined by gravimetric method. The gravimetric method was used to determine soil bulk density (BD) and actual soil moisture (ASM). The detail of soil physical properties determination followed the procedure as outlined by Klute (1986). Soil acidity $(\mathrm{pH})$ was determined in $\left(1: 2.5 \mathrm{H}_{2} \mathrm{O}\right)$ by $\mathrm{pH}$ meter method, while the organic $\mathrm{C}$ (C-org) and total $\mathrm{N}$ (N-tot) were determined by Walkley - Black and Kjeldahl methods, respectively. Other chemical properties such as cation exchange capacity (CEC) and base saturation (BS) were determined by the $\mathrm{NH}_{4} \mathrm{OAc}$ extraction methods. In addition, available $\mathrm{P}(\mathrm{P}-\mathrm{av})$ 
was determined by $\mathrm{HCl}$ and $\mathrm{NH} 4 \mathrm{~F}$ digestion method. Available K (K-av) was determined by the $\mathrm{NH}_{4} \mathrm{OAc}$ extraction method, while exchangeable $\mathrm{Al}$ (Al-exc) was determined by $\mathrm{KCl}$ extraction. All soil chemical analyses in detail were following procedures as outlined by Page et al. (1982). The biological properties of the total microorganism (TM) were determined by the cultural method. Earthworm population density (EPD) was determined by hand sorting method, by making soil monolith of $25 \mathrm{~cm} \times 25 \mathrm{~cm} \times 20 \mathrm{~cm}$ each, crumpled, and earthworms were counted by hand sorting, including its cocoon. The population density is stated in indiv. $\mathrm{m}^{-2}$ (Huising et al., 2008). Understory vegetation biomass weight (UVBW) and understory vegetation diversity (UVD) were determined in three subplots of $(1 \mathrm{~m} \mathrm{x} 1 \mathrm{~m})$. The vegetation species were counted, and all biomass was collected and weighed. Composite subsamples were taken from each plot, weighed, and oven-dried for four days at $60^{\circ} \mathrm{C}$ to obtain dray weight (UVDBW). The UVBW and UVBDW were expressed in $\left(\mathrm{g} \mathrm{m}^{-2}\right)$, and UVD units were expressed in $\left(\mathrm{spec} . \mathrm{m}^{-2}\right)$. All biological properties analyses follow the method as outlined in Page et al. (1982). Data were analyzed by analysis of variance (ANOVA) with $p<0.05$, and All significant parameters were analyzed further using Duncan's Multiple Range Test at $\mathrm{p}<0.05$.

\section{RESULTS AND DISCUSSION}

All agroecosystems studied were located close to each other, in the same soil system, most likely similar soil. Management of the rubber and oil palm plantations are relatively equal in that the plantations were less managed, such as fertilizer and weeding were not performed as suggested. This management is most likely represented smallscale rubber and oil palm plantations in general. In contrast, the food cropland was cultivated intensively, including soil tillage, fertilizer, pest, and weed control. The scrubland has wholly been abandoned for more than ten years, with no activity on this land.

Soil physical properties such as soil texture and $\mathrm{BD}$ consider as less likely to alter within decades (Bewket and Stroosnijder, 2003). This research, however, found that soil physical properties, especially silt and clay content, were significantly affected by agroecosystem in which the age of plantation ranging from 5 to 15 years old was included (Table 1). Besides the clay and silt contents, ASM was also significantly affected by agroecosystems, while sand and soil BD were not significantly affected. This finding seems in contrast with a previous statement. However, DMRT analyses showed that the age of agroecosystem, either oil palm or rubber, does not affect soil texture and BD, as shown in Table 2. The differences in silt and clay were found between the plantation agroecosystem (oil palm and rubber plantation) and food cropland.

Different from soil physical properties, some chemical properties may easily alter in a relatively short time, such as different seasons (Guo et al., 2020). The agroecosystem significantly affected soil chemical properties, including $\mathrm{C}$-org, $\mathrm{N}$-total, CEC, exchangeable-K, and available-P. In contrast, soil acidity, $\mathrm{BS}$, and TA were not significantly affected by the agroecosystems. Meanwhile, the agroecosystem did not affect soil biological properties such as TM, but it did for EPD, UVBW, UVBDW, and UVD. Result of statistical analysis of soil chemical and biological properties using ANOVA at the probability of $p<0.05$ was presented in Table 1 .

Tabel 1. Summary of statistical analysis using ANOVA of soil physical, chemical, and biological properties of various agroecosystem in Ultisol of Bengkulu

\begin{tabular}{lc}
\hline Variables & Calc. $\mathrm{F}^{1)}$ \\
\hline Physical Properties & \\
\hline Sand (\%) & $1.958 \mathrm{~ns}$ \\
Clay (\%) & $6.877^{* * *}$ \\
Silt (\%) & $6.198^{* *}$ \\
BD $\left(\mathrm{g} \mathrm{cm}^{-3}\right)$ & $0.044 \mathrm{~ns}$ \\
ASM $(\%)$ & $20.089^{* * *}$ \\
\hline Chemical Properties & \\
\hline pH $\mathrm{H}_{2} \mathrm{O}$ & $2.589 \mathrm{~ns}$ \\
Organic-C $(\%)$ & $6.871^{* * *}$ \\
Total-N \% & $8.009^{* * *}$ \\
CEC (cmol (+) kg ${ }^{-1}$ & $6.403^{* *}$ \\
BS (\%) & $2.543 \mathrm{~ns}$ \\
TA (cmol (+) kg ${ }^{-1}$ & $1.032 \mathrm{~ns}$ \\
Exchangeable-K (cmol $(+) \mathrm{kg}^{-1}$ & $20.932^{* * *}$ \\
Available-P $(\%)$ & $5.68^{* *}$ \\
\hline Biological Properties & \\
\hline TM & $0.456 \mathrm{~ns}$ \\
EPD (indiv. m $\left.{ }^{-2}\right)$ & $10.292^{* * *}$ \\
UVBW (g) & $10.194^{* * *}$ \\
UVBDW (g) & $13.305^{* * *}$ \\
UVD (spec. $\left.\mathrm{m}^{-2}\right)$ & $6.803^{* * *}$ \\
\hline
\end{tabular}

ns : non significantly different at $\mathrm{p}<0.05 ; * *$ : significant at $\mathrm{p}<0.01 ; * * *$ : significant at $\mathrm{p}<$ 0.001 


\section{Soil Physical Properties}

Agroecosystems significantly $(\mathrm{p}<0.01)$ affect silt and clay content and ASM of topsoil (0-20 $\mathrm{cm})$. To compare affected soil physical properties among the agroecosystems, DMRT was performed, and the result was presented in Table 2. Among all agroecosystems studied, none of them showed different silt and clay content but food crop agroecosystem. It has lower silt and higher clay content compared to other agroecosystems studied. The ASM, however, only in scrubland has significantly lower than all different agroecosystems studied. Sand content and BD showed no significant effect on agroecosystems.

Table 2. Result of DMRT for soil physical properties among the various agroecosystems in Ultisol of Bengkulu

\begin{tabular}{lccccc}
\hline $\begin{array}{l}\text { Agroecosys- } \\
\text { tems }\end{array}$ & $\begin{array}{c}\text { Sand } \\
(\%)\end{array}$ & Silt (\%) & $\begin{array}{c}\text { Clay } \\
(\%)\end{array}$ & $\begin{array}{c}\text { BD (g } \\
\left.\mathrm{cm}^{-3}\right)\end{array}$ & $\begin{array}{c}\text { ASM } \\
(\%)\end{array}$ \\
\hline 5-yr oil palm & 32.29 & $27.03 \mathrm{a}{ }^{1)}$ & $43.82 \mathrm{~b}$ & 1.31 & $23.66 \mathrm{a}$ \\
10-yr oil palm & 39.62 & $25.71 \mathrm{a}$ & $35.84 \mathrm{~b}$ & 1.21 & $23.88 \mathrm{a}$ \\
15-yr oil palm & 34.78 & $24.94 \mathrm{a}$ & $40.22 \mathrm{~b}$ & 1.36 & $24.40 \mathrm{a}$ \\
5-yr rubber & 28.20 & $23.89 \mathrm{a}$ & $44.77 \mathrm{~b}$ & 1.20 & $24.89 \mathrm{a}$ \\
10-yr rubber & 33.93 & $24.54 \mathrm{a}$ & $40.36 \mathrm{~b}$ & 1.17 & $23.48 \mathrm{a}$ \\
15-yr rubber & 29.59 & $25.00 \mathrm{a}$ & $45.47 \mathrm{~b}$ & 1.13 & $24.18 \mathrm{a}$ \\
Food crop & 21.63 & $8.53 \mathrm{~b}$ & $69.85 \mathrm{a}$ & 1.25 & $25.10 \mathrm{a}$ \\
Scrubland & 22.54 & $33.31 \mathrm{a}$ & $44.15 \mathrm{~b}$ & 1.50 & $15.92 \mathrm{~b}$ \\
\hline
\end{tabular}

Means within the same column followed by the same superscript were not significantly different at $\mathrm{p}<0.05$ by DMRT

\section{Soil Chemical Properties}

The result of the study indicated that soil $\mathrm{pH}$ $\left(\mathrm{H}_{2} \mathrm{O}\right)$, total acidity and base saturation were not different among agroecosystems as seen in Table 3. Also, the content of total $\mathrm{N}$ was similar among oil palm and rubber plantations of selected ages; however, both nutrients are significantly lower in scrub land and food crop. Total N was lowest in Scrubland even though it was not different from food crop. Scrubland exhibited the lowest available P while other agroecosystems had similar content of the nutrient. Available P in the scrubland was more than 4 folds lower than that in 10 years old rubber plantation ecosystem.

Table 3 also shows that organic carbon was different among agroecosystems. In general, older plantation had higher organic $\mathrm{C}$ than younger one. Fifteen years old palm plantation had $41.2 \%$ higher organic-C than five years old one, while that of rubber plantation was $50.1 \%$. Above all, organic-C was lowest in food crop but it was not different from five and ten years old oil palm plantations as well as 5 years old rubber plantation.

Exchangeable $\mathrm{K}$ and $\mathrm{CEC}$ also varied among agroecosystems (Table 3). The greatest CEC was achieved in agroecosystem of 15 years old rubber plantation, but it did not differ from that of 5 years old. Likewise, the lowest was in scrubland which was $48.8 \%$ lower than that in 15 year old rubber plantation. Similar fashion to CEC, exchangeable $\mathrm{K}$ was highest in 15 years old rubber plantation ecosystem while the lowest was in scrubland. The exchangeable- $\mathrm{K}$ in latter agroecosystem was more than 3 folds lower than the prior one. In general, older plantation has higher exchangeable $\mathrm{K}$ than the younger one.

\section{Soil Biological Properties}

There is no significant effect of agroecosystems on TM; in contrast, the EPD was significantly higher in scrubland compared to EPD in other

Table 3. Selected soil chemical properties among the various agroecosystems in Ultisols of Bengkulu

\begin{tabular}{|c|c|c|c|c|c|c|c|c|}
\hline $\begin{array}{l}\text { Agroeco sys- } \\
\text { tems }\end{array}$ & $\mathrm{pH} \mathrm{H} \mathrm{H}_{2} \mathrm{O}$ & Org-C & $\mathrm{N}$ total & BS & $\mathrm{P}_{2} \mathrm{O}_{5}$ & CEC & TA & Exch-K \\
\hline & & \multicolumn{4}{|c|}{ - - } & \multicolumn{3}{|c|}{----- $\left(\mathrm{cmol}(+) \mathrm{kg}^{-1}------\right.$} \\
\hline 5-yr oil palm & 5.06 & $3.18 \mathrm{~d}^{1)}$ & $0.27 \mathrm{a}$ & 11.77 & $9.54 \mathrm{a}$ & $17.03 \mathrm{~b}$ & 1.41 & $0.29 \mathrm{c}$ \\
\hline 10-yr oil palm & 5.45 & $3.93 \mathrm{bcd}$ & $0.23 \mathrm{a}$ & 11.77 & $7.96 \mathrm{a}$ & $16.79 \mathrm{~b}$ & 1.37 & $0.32 \mathrm{bc}$ \\
\hline 15-yr oil palm & 5.03 & $4.49 \mathrm{abc}$ & $0.32 \mathrm{a}$ & 13.54 & $12.92 \mathrm{a}$ & $17.25 \mathrm{~b}$ & 1.42 & $0.37 \mathrm{~b}$ \\
\hline 5 -yr rubber & 4.76 & $3.53 \mathrm{~cd}$ & $0.32 \mathrm{a}$ & 8.87 & $11.73 \mathrm{a}$ & $21.56 \mathrm{a}$ & 1.15 & $0.28 \mathrm{c}$ \\
\hline $10-\mathrm{yr}$ rubber & 4.58 & $4.80 \mathrm{ab}$ & $0.31 \mathrm{a}$ & 9.26 & $13.73 \mathrm{a}$ & $15.80 \mathrm{~b}$ & 1.70 & $0.30 \mathrm{bc}$ \\
\hline 15 -yr rubber & 4.81 & $5.33 \mathrm{a}$ & $0.31 \mathrm{a}$ & 13.39 & $12.31 \mathrm{a}$ & $23.17 \mathrm{a}$ & 0.98 & $0.45 \mathrm{a}$ \\
\hline Food crop & 4.93 & $2.97 \mathrm{~d}$ & $0.12 \mathrm{~b}$ & 9.26 & $9.88 \mathrm{a}$ & $15.66 \mathrm{~b}$ & 1.23 & $0.19 \mathrm{~d}$ \\
\hline Scrubland & 4.78 & $4.24 \mathrm{bc}$ & $0.08 \mathrm{~b}$ & 8.04 & $3.18 \mathrm{~b}$ & $15.57 \mathrm{~b}$ & 1.43 & $0.11 \mathrm{e}$ \\
\hline
\end{tabular}

Means within the same column followed by the same superscript were not significantly different at 
agroecosystems. The difference is as high as 3 to 16 times compared to all different agroecosystems. The scrubland also contains significantly higher UVBW and UVBDW than the other agroecosystems (Table 4). In contrast, the UVBW and UVBDW were significantly varied among the plantation agroecosystems. The UVD was highest in food cropland followed by 10 -year and 5-year oil palm plantation, while other agroecosystems were substantially lower.

Soil physical properties, including texture, $\mathrm{BD}$, and ASM, are similar in rubber and oil palm plantation and among the ages in similar plants. It means that using Ultisol in the range of 5 to 15 years for both rubber and oil palm plantation did not alter or deteriorate soil physical properties in studied. Bewket \& Stroosnijder (2003) stated that soil physical properties are less likely to change within decades. Another study, however, reported that using degraded soil for rubber jangle plantation can increase soil physical quality, as indicated by decreasing $\mathrm{BD}$ and field moisture capacity (Zeng et al., 2021). A similar trend of decreasing BD with time was reported in oil palm plantations ranging from two to 32 years old (Prawito et al., 2021).

The only difference in soil property is silt content in food cropland, which increases clay content because the sand content is relatively stable. It could be understood because food cropland with intensive tillage makes soil susceptible to erosion, where the silt faction is the most vulnerable for erosion both by wind or rainfall. Katra (2020) reported that silt was the most susceptible soil fraction to wind erosion. Clay fraction tends to form an aggregate make the clay fraction presence in the larger size. While the sand fraction has a large size that wind and water do not easily remove from the soil surface. In contrast, the silt fraction is small enough to be blown by wind and drift by water.

In general, selected soil chemical properties varied among agroecosystems selected in this study. Organic-C apparently is higher as oil palm and rubber get more mature. This might be associated with the addition of organic matter to the soil during littering year after year. Previous study indicated that litter production increased as rubber plantation more developed (N'Dri et al., 2018) Also, turnover of organic matter in rubber plantation is relatively higher than in oil plantation as indicated by the content of organic C (Table 3). Another study also noted that rubber forest had higher litter accumulation as reported by (Zeng et al., 2021). On the other hand, Food crop has lowest organic-C. This might have been associated with lower organic matter turnover to the soil since most plant biomass were carried during the harvest. Also, the land have never been fertilized using an organic amendment.

Total $\mathrm{N}$, available $\mathrm{P}$ and exchangeable $\mathrm{K}$ was consistently higher in plantation than food cropland and scrubland. This results might have been associated with higher organic matter. Decomposition of organic matter consequently releases nutrients such as nitrogen, phosphorous and potassium. Muktamar et al. (2020) indicated that organic amendment released phosphorus during the decomposition. Similar result was concluded by Yasin (2010) where total-N, available $\mathrm{P}$ and exchangeable $\mathrm{K}$ were not different among the age of 5, 10, 15, and 20 years old of rubber plantations. Surprisingly, scrubland has relatively high organic-C, but it has lower total$\mathrm{N}, \mathrm{P}_{2} \mathrm{O}_{5}$, and exchangeable $\mathrm{K}$.

Table 4. Result of DMRT for soil biological properties among the various agroecosystems in Ultisol of Bengkulu

\begin{tabular}{lccccc}
\hline Agroecosystems & $\begin{array}{c}\text { TM } \\
\left(\mathrm{x} 10^{4} \mathrm{CPU} \mathrm{g}^{-1}\right)\end{array}$ & $\begin{array}{c}\text { EPD } \\
\left(\text { indiv. } \mathrm{m}^{-2}\right)\end{array}$ & $\begin{array}{c}\text { UVBW } \\
\left(\mathrm{g} \mathrm{m}^{-2}\right)\end{array}$ & $\begin{array}{c}\text { UVBDW } \\
\left(\mathrm{g} \mathrm{m}^{-2}\right)\end{array}$ & $\begin{array}{c}\text { UVD } \\
\left(\mathrm{spec} . \mathrm{m}^{-2}\right)\end{array}$ \\
\hline 5-yr oil palm & 258.64 & $4.67 \mathrm{~b}^{1)}$ & $48.53 \mathrm{~cd}$ & $16.73 \mathrm{~cd}$ & $4.33 \mathrm{ab}$ \\
10-yr oil palm & 300.10 & $17.67 \mathrm{~b}$ & $24.87 \mathrm{~d}$ & $6.90 \mathrm{~d}$ & $5.50 \mathrm{a}$ \\
15-yr oil palm & 260.01 & $8.67 \mathrm{~b}$ & $58.67 \mathrm{~cd}$ & $18.90 \mathrm{~cd}$ & $2.33 \mathrm{c}$ \\
5-yr rubber & 265.07 & $8.00 \mathrm{~b}$ & $87.00 \mathrm{bcd}$ & $40.77 \mathrm{bcd}$ & $2.67 \mathrm{bc}$ \\
10-yr rubber & 323.45 & $10.67 \mathrm{~b}$ & $125.56 \mathrm{bc}$ & $52.83 \mathrm{bc}$ & $2.33 \mathrm{c}$ \\
15-yr rubber & 245.06 & $13.67 \mathrm{~b}$ & $78.50 \mathrm{bcd}$ & $31.43 \mathrm{bcd}$ & $2.67 \mathrm{bc}$ \\
Food crop & 245.08 & $3.00 \mathrm{~b}$ & $159.60 \mathrm{~b}$ & $62.20 \mathrm{~b}$ & $6.00 \mathrm{a}$ \\
Scrubland & 254.31 & $52.67 \mathrm{a}$ & $292.07 \mathrm{a}$ & $134.10 \mathrm{a}$ & $3.00 \mathrm{bc}$ \\
\hline
\end{tabular}

Means within the same column followed by the same superscript were not significantly dif- 
Cation Exchange Capacity is always higher in plantation than in food cropland and scrubland. This result is attributed to the content of organic matter as indicated by organic carbon. Decomposition of organic matter produces organic acids mainly humic and fulvic acids rich in carboxyl and phenolic functional groups. This functional groups will contributes to negative charges of the soil (Spark, 2003), increasing CEC of the soil.

Scrubland in this study was more identified as degraded or marginal land. The land had been used for food crops, but due to its being heavily weathered, it was abandoned and developed as a scrubland for more than ten years. The highest earthworm population densities $\left(52,67\right.$ indiv. $\left.\mathrm{m}^{-2}\right)$ were found in the scrubland ecosystems compared to other agroecosystems studied, ranging from 3 to 17.7 indiv. $\mathrm{m}^{-2}$. It is in line with the abundance of biomass vegetation $\left(292,07 \mathrm{~g} \mathrm{~m}^{-2}\right)$ in the ecosystem than others $\left(24.87-159.60 \mathrm{~g} \mathrm{~m}^{-2}\right)$. In addition, unlike in the oil palm, rubber, and food crop agroecosystem, the absence of soil tillage and pesticide and inorganic fertilizer application make the ecosystem suitable for earthworm niece. The effect of pesticide and soil tillage on earthworm population has been reported by Paoletti et al. (1998). They found that the earthworm population was significantly affected by the presence of $\mathrm{Cu}$ and $\mathrm{Zn}$ from pesticide application. In addition, they also found that soil tillage is severely decreased the earthworm population.

Meanwhile, Singh et al. (2020) reported that soil under cultivation has less earthworm population than uncultivated soils. It is because of the absence of soil disturbance in natural soils. Singh et al. (2016) concluded that abiotic factors such as soil $\mathrm{pH}$, texture, organic carbon and land use type, and soil tillage significantly affected earthworm population and distribution. EPD was most likely influenced by organic matter quality as reported by Nurhayati et al. (2012) that earthworm prefers lowquality organic matter (high $\mathrm{C} / \mathrm{N}$ ratio). Because of low organic matter contents, more energy is required by earthworms than do low $\mathrm{C} / \mathrm{N}$ ratio organic matter. The ratio of $\mathrm{C} / \mathrm{N}$ in the scrubland studied is 58 compared to $\mathrm{C} / \mathrm{N}$ in plantation and food crop agroecosystems ranging from 11 to 25 .

Although the UVBW showed that the scrubland was the highest among the other agroecosystems, the UVD did not show the same trend. In contrast, UVD of the scrubland was comparable to the UVD in 5 and $15 \mathrm{yr}$ of rubber and $5 \mathrm{yr}$ of oil palm plantation. It suggests that vegetation in scrubland was much larger than understory vegetation due to controlling weed activities in the plantation.
The total microbial population (TM) is between $245.06-323.45 \times 10^{4} \mathrm{CPU} \mathrm{g}^{-1}$ showing no significant effect of agroecosystem. A previous study, conducted in a subtropical climate with four seasons, resulted that the total microbial population was more determined by season than soil tillage and agroecosystem (Zang et al., 2012). It may explain the similarity of TM in a various agroecosystems in this study, because Bengkulu doesn't have any significantly different seasons during the year (temperature and rainfall). In addition, Guo et al. (2020) reported that the microbial community was more affected by crop rotation than the crop stage in an annual crop. It may also apply to the result of this study since there was no crop rotation for the plantation agroecosystem, while the crop stage represented by plantation age did not affect the TM.

\section{CONCLUSION}

Rubber and oil palm plantations agroecosystems of $5 \mathrm{yr}, 10 \mathrm{yr}$ and $15 \mathrm{yr}$ ages do not affect soil properties including soil texture, soil BD, ASM, TM, TA. On the other hand, both agroecosystems enhances soil chemical properties than food cropland and scrubland as indicated by the improvement of organic-C, total- $\mathrm{N}$, available $\mathrm{P}$, exchangeable $\mathrm{K}$ and CEC of Ultisols. Older plantation also provides higher soil chemical improvement than younger one. This finding is significant to soil or management mainly Ultisols.

\section{References}

Amoah, A. A., Seuge, M., Miyagawa, S. \& Itou, K. (2012). Effects of soil fertility management on growth, yield, and water-use efficiency of maize (Zea mays L.) and selected soil properties. J. Com. Soil Sci. and Plant Anal., 4(6), 924-935. doi.org/10.1080/00103624. 2012.653028.

Bahr, E., Chamba-Zaragocin, D., Fierro-Jaramillo, N., Witt, A. \& Makeschin, F. (2015). Modeling of soil nutrient balances. flows and stocks revealed effects of management on soil fertility in south Ecuadorian smallholder farming systems. Nutrient Cycling in Agroecosystems, 101, 55-82.

Bewket, W. \& Stroosnijder, L. (2003). Effects of agroecological land use succession on soil properties in Chemoga watershed, Blue Nile basin, Ethiopia. Geoderma, 111(1), 85 - 98. doi.org/10.1016/S0016-7061(02)00255-0.

Ebabu, K., Tsunekawa, A., Haregeweyn, N., Yibeltal, M. (2003). Effects of agroecological land use succession on soil properties in Chemoga watershed. Blue Nile basin. Ethiopia. 
Geoderma, 111(1), 85-98. DOI: 10.1016/ S0016-7061(02)00255-0.

Emadi, M., Bhagernejad, M. \& Memarian, R. (2009). Effect of land-use change on soil fertility characteristics within water-stable aggregates of two cultivated soils in northern Iran. Land Used Polecy, 26(2), 452-457. doi.org/10.1016/j.landusepol.2008.06.001.

Global Forest Watch (June, 2018). Indonesian Soil Types. retrieve from : http://gfw2-data.s3. amazonaws.com/country/idn/zip/idn soil type.tif.zip.

Guo, Z., Wan, S., Hua, K., Yin, Y., Chu, H.Y., Wang, D. \& Guo, X. (2020). Fertilization regime has a greater effect on soil microbial community structure than crop rotation and growth stage in an agroecosystem. Applied Soil Ecology, 149, 103510. doi.org/10.1016/ j.apsoil.2020.103510.

Huising, E. J., Coe, R., Cares, J. E., Louzada, J. N., Zanetti, R., Moreira, F. M. S., Susilo, F. X., Konate, S., van Noordwijk, M. \& Huang, S.P. (2008). Sampling Strategy and Design to Evaluate Below-ground Biodiversity. In F. M. S. Moreira., E. J. Huising, and D. E. Bignell (eds). A Handbook of Tropical Soil Biology ( $1^{\text {st }}$ ed.). Routledge. London. Sterling. V.A.:17-41. doi.org/10.4324/9781849770286.

Jin, J., Zue, Y., Ye, H., Shen, C. \& Huang, Y. (2011). Effect of land use and soil management practices on soil fertility quality in North China cities' urban fringe. Afr. J. Agric. Res., 6(9), 2059-2065. http://doi.org/ 10.5897/AJAR11.174.

Katra, I. (2020). Soil Erosion by Wind and Dust Emission in Semi-Arid Soils Due to Agricul- tural Activities. Agronomy, 10(1), 89; https:// doi.org/10.3390/agronomy10010089.

Klute. A. (1986). Methods of Soil Analysis. Part 1. Physical and Mineralogical Methods $2^{\text {nd }}$ Edition.

Muktamar, Z., Lifia, L., Adiprasetyo, T. (2020). Phosphorus availability as affected by the application of organic amendments in Ultisols. Sains Tanah. Jurnal of Soil Science and Agroclimatology, 17(1), 16-22. DOI:10.20961/ stjssa.v17i1.41282.

N'Dri, J.K., Gue'I, A. M. Edoukou, E. F., Ye'o, J. G., N'Guessan, K. K. \& Laferlof. J. (2018). Can litter production and litter decomposition improve soil properties in the rubber plantations of different ages in Co te d'Ivoire? Nutr Cycl Agroecosyst Springer Science+Business Media B.V., part of Springer Nature 2018 . https://doi.org/10.1007/s10705-018-9923-9.

Nurhayati, N., Arisoesilaningsih, E., Suprayogo, D. \& Hairiah, K. (2012). Earthworm population density in sugarcane cropping system applied with various quality of organic matter. The Journal of Tropical Life Science, 2 (3), $103-109$.

Page. A. L.. Miller, R.H., Keeney, D.R. (1989). Methods of Soil Analysis. Part 2. Chemical and Biological Properties $2^{\text {nd }}$ Edition. ASA. SSSA. Madison Wisconsisn. USA.

Paoletti, M.G., Sommagio, D., Fafretto, R.F., Petruzzellibe, G., Pezzarossa, B., Barbafieri, M. (1998). Earthworms as useful bioindicators of agroecosystem sustainability in orchards and vineyards with different inputs. Applied Soil Ecology, 10(1), 137-150. doi.org/10.1016/S0929-1393(98)00036-5. 